\title{
Effect of antiretroviral drugs on prolactin in HIV infected pregnant women
}

\author{
Chukwubike UDOKA OKEKE ${ }^{1}$, Patrick UGOCHUKWU AGBASI ${ }^{1 *}$, Hope OKORIE ${ }^{2}$ \\ and Ferdinand EZEIRUAKU ${ }^{3}$ \\ ${ }^{1}$ Department of Prosthesis and Orthopaedic Technology, School of Health Technology, Federal University of \\ Technology, Owerri, Imo State, Nigeria. \\ ${ }^{2}$ Department of Medical Laboratory Science, Imo State University, Owerri, Imo State, Nigeria. \\ ${ }^{3}$ Department of Medical Laboratory Science, Niger Delta University, Wilberforce Island, \\ Bayelsa State, Nigeria. \\ *Corresponding author; E-mail: patagbasi@yahoo.com
}

\begin{abstract}
The world has finally settled living with Human immunodeficiency Virus (HIV) with no cure discovered so far. Yong people with HIV infection under HIV management drugs get married and eventually end up being pregnant and bearing babies. The need therefore to investigate the effect of HIV infection and antiretroviral drugs on body chemistry especially the hormones concerned with pregnancy and lactation cannot be over emphasized as this is important to intervene when necessary for the overall benefit for the mother and child. We investigated the effect of anti-retroviral drugs and human immune deficiency virus (HIV) infection on prolactin production and stimulation in HIV-infected pregnant women. A total of 120 subjects participated in the study. Sixty (group 1) of these subjects were HIV seropositive pregnant women who commenced treatment with zidovudine in combination with lamivudine, that is highly anti-retroviral therapy (HAART) at $2^{\text {nd }}$ trimester. The $2^{\text {nd }}$ group made up of $60 \mathrm{HIV}$ seronegative pregnant women who received no drug and as control to the study. The blood samples of both groups were collected at the beginning of the second and at the end of the third trimesters. For group 1 (seropositive pregnant women), the blood collection was done just before commencing the HAART treatment. The prolactin level of HIV seropositive pregnant women were significantly $(\mathrm{P}<0.05)$ lower than the HIV seronegative pregnant women at the $2^{\text {nd }}$ trimester. Also, the prolactin level of HIV seropositive pregnant women at $2^{\text {nd }}$ trimester was not significantly increased $(P>0.05)$ compared with third trimester level. The reverse was the case with HIV seronegative pregnant women where prolactin level of $3^{\text {rd }}$ trimester was significantly increased when compared with $2^{\text {nd }}$ trimester. HIV infection has prolactin suppressive effect on pregnant women and HAART treatment did not significantly raise prolactin level.
\end{abstract}

(C) 2014 International Formulae Group. All rights reserved.

Keywords: Prolactin, pregnancy, HIV, highly active retroviral therapy (HAART).

\section{INTRODUCTION}

Prolactin is a protein hormone secreted by pituitary mammotrophic cells. High level of it can be produced during pregnancy as a result of increase in the number of mammotrophic cells which is also caused by high concentration of circulating oestrogen.

Over or under production of hormones can contribute to a variety of medical conditions. Diseases such as HIV that affect 
the whole body can interfere with proper endocrine function / secretion, and hormone in turn, can affect disease progression (Highleyman, 2004). Garcia et al. (2002) reported that studies have shown that HIV itself could affect the body's ability to produce and maintain hormone levels. Patients with acquired immune deficiency syndrome (AIDS) have been reported to have abnormalities of endocrine organs frequently (Fontes et al., 2003). Merenich et al. (1990) reported change in levels of prolactin, estradiol, testosterone, and thyroxine in HIV patients. Ram et al. (2004) stated that there was lower free prolactin level in HIV patients and pointed out that the high level of prolactin in HIV patients was a result of low biologic active macro-prolactin in the circulation. Montero et al. (2000) reported that high level of prolactin in HIV-infected patients does not correlate with plasmic viral burden. Physiopathology of endocrine dysfunction in HIV/AIDS infected patients could not be succinctly explained. Verges et al. (1990) suspected the involvement of interleukin-1 in stimulation of corticotrophin-releasing hormone secretion and its direct action on the glycoprotein capsule of the virus (gp 120) which is similar to that of the hormone.

In HIV-infected pregnant women, antiretroviral drugs are used to reduce vertical transmission of HIV infection from mother to child. Suksomboon et al. (2007) stated that zidovudine alone or in combination with lamivudine and nevirapine monotherapy were found to be effective for the prevention of mother - to - child transmission of HIV, and also were beneficial in reducing the risk of infant death. Apart from these beneficial effects, antiretroviral drugs can cause adverse effects such as anaemia, pre-term delivery (Areechokechai et al., 2009). The use of antiretroviral drugs has also been associated with fluctuation in level of some reproductive hormones in HIV seropositve patients. Santro et al. (2005) stated that Highly Active Antiretroviral Therapy (HAART) increased prolactin level in HIV infected patients.

This study is carried out to investigate the effect of antiretroviral drugs on prolactin (which is a pregnancy hormone that initiates lactation and controls the metabolism of fat, carbohydrate, calcium, vitamin $\mathrm{D}$, and foetal lung development) among HIV-infected pregnant women who were placed on antiretroviral drugs.

\section{MATERIALS AND METHODS}

The human subjects used in the study and prolactin analysis

This study was carried out on randomly selected one hundred and twenty (120) pregnant women attending antenatal clinic in General Hospitals in Rivers State, Nigeria. Sixty of these women were HIV-seronegative (non- infected) and they were regarded as control group, while the rest of 60 pregnant women were HIV seropositive (HIV-infected) as at $2^{\text {nd }}$ trimester of this study. The HIVinfected women commenced the antiretroviral drugs at $2^{\text {nd }}$ trimester after initial sample collection. Initial blood sample collection was also done at second trimester on control group (HIV seronegative pregnant women). Samples were also collected from these two groups at the end of $3^{\text {rd }}$ trimester of pregnancy to estimate the prolactin level using enzymelinked immunosorbent-assay (ELISA) method as described by (Thorner et al., 1974).

\section{Ethics}

Ethics approval was obtained from Ethics Committee of School of Health Technology, Federal University of Technology Owerri, Nigeria. Informed consent was also obtained from the subjects. 


\section{Statistical analysis}

The data we generated were analysed using statistical package for social sciences (SPSS) version 16. Student's t test was used to test the difference between two groups of continuous variables and $\mathrm{P} \leq 0.05$ is considered significant.

\section{RESULTS}

From Table 1 and Figure 1 , we observed that, there was a significant $(\mathrm{p}<0.05)$ increase in prolactin level from $104.71 \pm 7.68$ $\mathrm{ng} / \mathrm{ml}$ in the $2^{\text {nd }}$ trimester to $150.75 \pm 4.82$ $\mathrm{ng} / \mathrm{ml}$ in the $3^{\text {rd }}$ trimester of pregnancy among non-infected pregnant women, but there was no significant $(\mathrm{p}>0.05)$ increase in prolactin level among seropositive pregnant women (from $58.72 \pm 5.28 \mathrm{ng} / \mathrm{ml}$ in $2^{\text {nd }}$ trimester to $67.06 \pm 4.92 \mathrm{ng} / \mathrm{ml}$ ) in the $3^{\text {rd }}$ trimester after receiving HAART from their $2^{\text {nd }}$ to $3^{\text {rd }}$ trimester.

In Table 1 also, there was a significantly ( $>0.05)$ higher level of prolactin in noninfected pregnant women, $104.71 \pm 7.68$ $\mathrm{ng} / \mathrm{ml}$, compared to HIV-infected pregnant women $58.72 \pm 5.28 \mathrm{ng} / \mathrm{ml}$ at $2^{\text {nd }}$ trimester. This significantly $(\mathrm{P}<0.05)$ high level in prolactin was also observed when comparison was made at $3^{\text {rd }}$ trimester between the noninfected, $(150.75 \pm 4.82 \mathrm{ng} / \mathrm{ml})$, and HIVinfected, $(67.06 \pm 4.92 \mathrm{ng} / \mathrm{ml})$, pregnant women.

Table 1: Comparative prolactin level of HIV-infected and non-infected pregnant women at $2^{\text {nd }}$ and $3^{\text {rd }}$ trimester.

\begin{tabular}{cccc}
\hline & $\begin{array}{c}\text { Non-infected group } \\
(\mathbf{n = 6 0})\end{array}$ & $\begin{array}{c}\text { HIV-infected group } \\
(\mathbf{n = 6 0})\end{array}$ & P-value \\
\hline $2^{\text {nd }}$ trimester value $(\mathrm{ng} / \mathrm{ml})$ & $104.71 \pm 7.68$ & $58.72 \pm 5.28$ & $\mathbf{P}<\mathbf{0 . 0 5}$ \\
3rd trimester value $(\mathrm{ng} / \mathrm{ml})$ & $150.75 \pm 4.82$ & $67.06 \pm 4.92$ & $\mathbf{P}<\mathbf{0 . 0 5}$ \\
P-value & $\mathbf{P}<\mathbf{0 . 0 5}$ & $\mathbf{P}>\mathbf{0 . 0 5}$ & \\
\hline
\end{tabular}

Values are expressed as mean \pm SEM and regarded as significant at $\mathrm{p} \leq 0.05$.

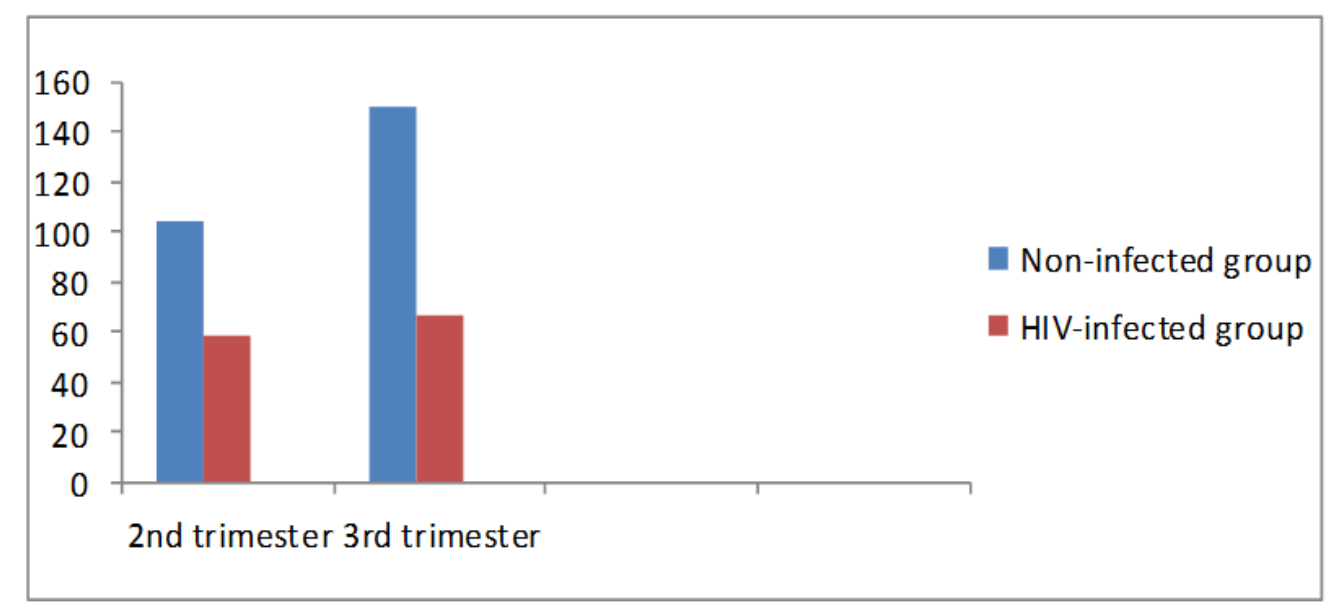

Figure 1: Histogram of means of the prolactin levels at different trimesters. 


\section{DISCUSSION}

In this study, we observed that prolactin level was significantly increased in non HIV infected pregnant women at $2^{\text {nd }}$ and $3^{\text {rd }}$ trimesters respectively than in the corresponding trimesters of HIV-infected group. The reduction in the prolactin level seen among the infected group might be attributed to the effect of HIV infection on these women. Ram et al. (2004) and coworkers stated that there was lower free prolactin level in HIV patients. Merenish et al. (1990) also reported a change in level of prolactin and some steroid hormone in patients infected with HIV. A more recent study conducted by Ogundahunsi et al. (2011) on amenorrheic HIV-positive women reported significant decrease in leutenizing hormone (LH), follicle stimulating hormone (FSH), and prolactin level. Although the HIV patients used in these studies were non pregnant women, their findings were in agreement with the present study. HIV infection can directly affect endocrine glands thereby causing HIVendocrinopathy. It was stated by Sinha et al. (2011) that complex interaction between HIV infection and endocrine system may be manifested as subtle biochemical and hormonal perturbation to overt glandular failure.

Normally, prolactin increases with increase in gestational age in pregnant women primarily to induce milk production at parturition. This was observed in non-infected pregnant women in this study and the increase from $2^{\text {nd }}$ trimester to $3^{\text {rd }}$ trimester was significantly high. There was also no significant increase in prolactin level at the end of $3^{\text {rd }}$ trimester among HIVinfected pregnant women who commenced antiretroviral treatment when compared with that of $2^{\text {nd }}$ trimester. It is known that antiretroviral therapy reduces human immunodeficiency viral load and up-regulates CD4+ count which translates to improved health condition of HIV/AIDs sufferers, but menstrual irregularities persists despite antiretroviral therapy use (Harrington et al., 2000). This goes to suggest that HIV/AIDS may possess depressive effect on reproductive hormones, which the use of anti-retroviral agents could not redress.

\section{Conclusion}

In the light of the foregoing, human immunodeficiency virus infection may possess suppressive effect on prolactin secretion in pregnant women and anti retro viral therapy did not revise this effect.

\section{REFERENCES}

Highleyman L. 2004. HIV and hormones. Beta Bulletin of Experimental Treatments for AIDS, 16(4): 34 - 44.

Garcia A, Jennifer M, Heidi N, Olufs C, Rappoport G. 2002. Treatment issues for Women. AIDS Community Research Initiative of America, 1-5.

Fontes R, Vangeloti A, Pires ML, Lima MB, Dimetz F, Faulhaber M, Faria R Jr, Meirelles RM. 2003. Endocrine disorders in Brazilian patients with acquired immune deficiency syndrome. Clinical Infectious Disease, 37(20): 137-141.

Merenich JA, McDermott MT, Asp AA, Harrison SM, Kidd GS. 1990. Evidence of endocrine involvement early in the course of human immunodeficiency virus infection. Journal of Clinical Endocrinology and Metabolism, 70(3): 563-565.

Ogundahunsi OA, Ogundipe MO, Akinola NO, Soyinka OO, Odewabi AO, Oyegunle VA. 2011. The effect of HIV and antiretroviral therapy on fertility hormones in amenorrheic HIV-positive women. African Scientist, 11(3): 143-146.

Ram S, Acharya S, Fernando JJ, Anderson NR, Gama R. 2004. Serum Prolactin in human Immunodeficiency Virus infection. Clinical Laboratory, 50(9-10): 617 - 620.

Montero A, Giovannoni AG, Sen L. 2000. Hyperprolactinemia is a frequent finding in HIV infection but does not correlate with viral burden. Medicina, 60(4): 427 - 430 .

Verges B, Chavanet P, Desgress J, Kisterman JP, Putelat R. 1990. Endocrine 
abnormalities in HIV infections. Presse Medicale, 19(27): 1267-1270.

Suksomboon N, Poolsup N, Ket-Aim S. 2007. Systematic review of the efficacy of antiretroviral therapies for reducing the risk of mother to child transmission of HIV infection. Journal of Clinical Pharmacotherapy, 32(3): 293 - 311.

Thorner MO, McNeilly AS, Hagan C. 1974. Long term treatment of galactorrhea and hypogonadism with bromocriptine. $\mathrm{Br}$. Med. J. 2: 4.

Areechokechai D, Bowonwatanuwong C, Phonrat B, Maek-a-Nantawat W, Pitisuttithum P. 2009. Pregnancy outcome among HIV-infected women undergoing antiretroviral therapy. Open AIDS Journal, 3: 8-13.
Santoro N, Arnstem JH, Buono D, Howward AA, Schoenbaum EE. 2005. Impact of street drug use HIV Infection, and highly active anti retroviral therapy on reproductive hormones in middle - aged women. Journal of Women's Health, 14(10): 898 - 905.

Sinha U, Sengupta N, Mukhopadhyay P, Roy SK. 2011. Human immunodeficiency virus endocrinopathy. Indian Journal of Endocrinology and Metabolism, 15(4): 251-260.

Harrington M, Carpenter CC. 2000. Hit HIV-1 hard, but only when necessary. Lancet; 355(9221): 2147- 2152. 